Discussion Paper No. 06-028

\title{
The Export-Growth Relationship: Estimating a Dose-Response Function
}

Helmut Fryges

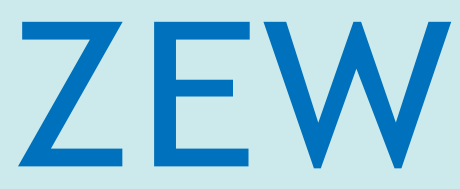

Zentrum für Europäische Wirtschaftsforschung $\mathrm{GmbH}$

Centre for European

Economic Research 
Discussion Paper No. 06-028

\title{
The Export-Growth Relationship: Estimating a Dose-Response Function
}

\author{
Helmut Fryges
}

Download this ZEW Discussion Paper from our ftp server:

ftp://ftp.zew.de/pub/zew-docs/dp/dp06028.pdf

Die Discussion Papers dienen einer möglichst schnellen Verbreitung von neueren Forschungsarbeiten des ZEW. Die Beiträge liegen in alleiniger Verantwortung der Autoren und stellen nicht notwendigerweise die Meinung des ZEW dar.

Discussion Papers are intended to make results of ZEW research promptly available to other economists in order to encourage discussion and suggestions for revisions. The authors are solely responsible for the contents which do not necessarily represent the opinion of the ZEW. 


\section{Non-technical Summary}

The relationship between individual firms' export behaviour and firm performance has been studied extensively in the economic literature. Most studies from the field of economics only distinguish between exporting and non-exporting companies. Whether or not exporting has a positive effect on firm performance might, however, not only depend on a firm's export status, but might be a function of the extent of the firm's export activities. On the one hand, there are firms that only occasionally receive some unsolicited orders from abroad, whereas, on the other hand, some firms pro-actively exploit the potential of the foreign market, generating a high percentage of their total sales abroad.

This paper introduces the newly developed generalised propensity score method (GPS) to the literature examining the export-performance relationship. Similar to traditional matching techniques that are based on a binary treatment variable (e.g., the firms' export status), the GPS method removes all the bias associated with firm-specific differences between exporting and non-exporting firms. However, the GPS method allows for continuous treatment, that is, in our case, different levels of the firms' export activities.

The GPS method is illustrated using a data set of about 200 young technology-oriented firms in Germany and the UK. Using the GPS method, a dose-response function is estimated that depicts the conditional expectation of the firms' sales growth rate (as a measure of firm performance) given the level of export activities and the generalised propensity score. The estimated dose-response function confirms the inverted $U$-shaped relationship between the degree of internationalisation (measured as the share of exports in total sales) and firm performance that has frequently been found in studies from the field of international management. 


\title{
The Export-Growth Relationship: Estimating a Dose-Response Function
}

by

Helmut Fryges*

April 2006

\begin{abstract}
The relationship between individual firms' export behaviour and firm performance has been studied extensively in the economic literature. However, most studies from the field of economics only distinguish between exporting and non-exporting companies, using the firms' export status as a binary treatment variable and comparing the performance of exporting and non-exporting firms. This paper introduces the newly developed generalised propensity score (GPS) methodology to the literature of individual firms' export behaviour. Instead of a binary treatment variable, the GPS method allows for continuous treatment, that is, different levels of the firms' export activities. Based on the GPS methodology, a dose-response function is estimated, depicting the relationship between the firms' pre-treatment export-sales ratio and their subsequent sales growth rate as a measure of firm performance.
\end{abstract}

Keywords: Degree of internationalisation, continuous treatment, generalised propensity score, dose-response function, high-technology industries.

JEL Classification: F23, L60, L86

* Centre for European Economic Research (ZEW), Department of Industrial Economics and International Management, P.O. Box 103443, D-68034 Mannheim, Germany, e-mail: fryges@zew.de 


\section{Motivation}

The relationship between individual firms' export behaviour and firm performance has been studied extensively in the economic literature since the mid 1990s. Wagner (2005) surveys 45 microeconometric studies with data from 33 countries published between 1995 and 2004. He concludes that "exporters are more productive than non-exporters, and that the more productive firms self-select into the export markets, while exporting does not necessarily improve productivity” (Wagner 2005: 12). In addition to the firms’ productivity, other measures of firm performance have been examined, among them (employment and sales) growth (e.g., Bernard and Jensen 1999; Fryges 2004), wages (e.g., Wagner 2002) and the probability of survival (e.g., Bernard and Wagner 1997; Bernard and Jensen 1999). In most cases, these studies confirm Wagner's conclusion: The superior performance of internationally active firms is a result of self-selection of "good” firms into the international market. Conversely, there is little evidence that internationalisation has a causal effect on firm performance.

However, most of the studies cited above only distinguish between exporting and nonexporting companies. The firms' export status is used as a binary treatment variable and the performance of exporting and non-exporting firms is compared applying different econometric methods (e.g., simultaneous equation models, matching techniques). Whether or not exporting has a positive effect on firm performance might, however, not only depend on a firm's export status, but might be a function of the extent of the firm's export activities. On the one hand, there are firms that only occasionally receive some unsolicited orders from abroad, whereas, on the other hand, some firms pro-actively exploit the potential of the foreign market, generating a high percentage of their total sales abroad. 
In the economic literature, only few studies investigate the influence of varying degrees of internationalisation on performance, among them the studies by Liu et al. (1999) and Castellani (2002) which both find a positive effect of the share of exports in total sales on firm performance. The impact of varying degrees of a firm's international business activities on its performance has, however, frequently been discussed in the international business literature since the 1980s. Early studies hypothesise and empirically confirm a (in most cases positive) linear relationship between the degree of internationalisation and performance (e.g., Bühner 1987 and Grant 1987). More recently published studies postulate a curvilinear relationship: Internationally active firms are assumed to realise economies of scale in production and access new technologies, leading to a higher level of performance the higher the firm's extent of international business activities. However, when a firm increases its international engagement the costs of coordination and control also rise and sometimes begin to escalate when a critical threshold of internationalisation is exceeded. Thus, any further international expansion induces a decrease in performance. ${ }^{1}$ Such an inverted $U$-shaped relationship is empirically supported by research by Geringer et al. (1989) and Gomes and Ramaswamy (1999). Some empirical studies even argue in favour of multiple waves in the relationship between a firm's level of foreign involvement and its performance (cf. Hitt et al. 1994, Sullivan 1994a, and Riahi-Belkaoui 1998).

The studies from the field of economics and those from the field of international business research differ from each other with respect to the applied econometric method. Wagner (2002) introduced matching techniques to the literature that empirically analyses the export-performance relationship. His analysis was restricted to the case where

1 See Gomes and Ramaswamy (1999) for an overview of theoretical arguments on how a firm's degree of internationalisation may be linked with its performance. 
the treatment is binary: All exporting firms are matched to a non-exporting firm with the same or a very similar propensity score that results from a probit regression estimating the individual firm's probability of having international sales. Imbens (2000) and Hirano and Imbens (2004), however, extend this traditional propensity score methodology that was developed by Rosenbaum and Rubin (1983) by defining a generalisation of the binary treatment propensity score, which they label the generalised propensity score (GPS). The GPS method allows for continuous treatment, that is, in our case, different levels of the firms' export activities. Imbens (2000) shows that, similarly to the case of binary treatment, adjusting for the GPS removes all the bias associated with differences in pre-treatment variables between treated and non-treated individuals or firms. Based on the GPS, Hirano and Imbens (2004) further estimated a dose-response function that depicts the conditional expectation of outcome (firm performance in our case) given the continuous treatment (level of export activities) and the GPS, evaluated at any level of the continuous treatment variable.

In this paper, I will introduce the GPS method to the literature examining the exportperformance relationship and estimate a dose-response function of firm performance in dependence of firms' degrees of internationalisation. The application of the GPS method will be illustrated using a data set of about 200 young technology-oriented firms in Germany and the UK that was collected by means of two surveys conducted in 1997 and 2003, respectively. In the related literature, numerous measures of a firm's degree of internationalisation and its performance are used. The share of total revenues generated abroad, denoted export-sales ratio or export intensity, is the most widely adopted measure of the degree of internationalisation (see Sullivan 1994b for an extensive review) and is therefore also used in this paper. Firm performance is measured as the firm's sales growth rate. Since the foreign market could be regarded as an expansion of the domestic market, firms can realise economies of scale and an ensuing increase in 
sales (and employment) by carrying out export activities. This mechanism is known in the related literature as export-led growth (see Feder 1982). In fact, the potential of the international market to sustain long-term company growth was ranked as the most important motive for international business activities by the majority of both German and UK firms in our sample in 1997 (see Bürgel et al. 2004). However, an exporter that has already attained a relatively high export intensity prior to the regarded growth period (i.e., in our case, from 1997 to 2002) can be expected to grow at a smaller rate than a firm with a medium-level export-sales ratio. If a firm already generates a high share of its total sales abroad, a further international expansion will become difficult because of the increasing costs of coordination and control that tie up the firm's (financial) resources and restrict its growth potential.

Before estimating the dose-response function in section 3, however, I will present the data set used for the analysis along with some descriptive statistics (section 2). Implications and possible extensions of the analysis will briefly be discussed in section 4 .

\section{Data and Descriptive Analysis}

This paper examines the export-growth relationship of technology-based firms in Germany and the UK. Technology-oriented firms are identified using the definition of hightechnology manufacturing sectors in the UK established by Butchart (1987). The identified manufacturing industries are listed in Table 1 and augmented with a number of selected service sectors (cf. Bürgel et al. 2004).

>>> insert Table 1 about here $\quad<<<$

The data for the empirical analysis result from two surveys simultaneously carried out in Germany and the UK. The source data set originates from Dun \& Bradstreet in the 
UK and Creditreform² in Germany. From each country's population of firms that were operating in at least one high-tech sector as defined by Butchart (1987) and were founded as legally independent companies between 1987 and 1996, a stratified random sample of 2,000 firms was drawn and subsequently contacted in winter 1997/1998 via a written questionnaire. The first survey was carried out by the London Business School in the UK and the Centre for European Economic Research (ZEW) in Germany. 362 completed questionnaires returned from the UK along with 232 questionnaires from Germany.

In order to assess the development of this sample of 600 new technology-based firms, a joint research team from the University of Exeter and the ZEW prepared a new survey in which firms that had previously responded were to be contacted a second time. The second survey was conducted in 2003 via computer-aided telephone interviews (CATI). 244 interviews were successfully completed. After performing several consistency checks, 217 companies were retained in the data set for empirical analyses.

In both countries, more than two-thirds of the responding firms had international sales in 1997 (German firms: 68.4\%; UK firms: 76.5\%). In the same year, the firms in our sample generated an average of $23.5 \%$ of total sales in the foreign market (German firms: $16.5 \%$; UK firms: $28.9 \%$ ). It is important to note that these numbers do not only include exporting firms but also cover companies without international sales. The latter group of firms decided that their optimal volume of exports was zero. The average share of total turnover the sample's exporters generated through foreign sales in 1997 amounted to 32.7\% (German firms: 24.2\%; UK firms 38.8\%). The percentage of exporting firms in which non-domestic revenues exceeded $50 \%$ of total revenues was $26.5 \%$

2 As Germany's largest credit rating agency, Creditreform has the most comprehensive database of German firms at its disposal. Creditreform provides data on German firms to the Centre for European Economic Research (ZEW) for research purposes. Dun \& Bradstreet is the UK equivalent. 
(German firms: 15.4\% ; UK firms: 34.4\%). As shown by the figures in parentheses, the extent of UK firms' export activities exceeds that of their German rivals. As Bürgel et al. (2004) argued, this might be the case because UK exporters more pro-actively exploit the sales potential of foreign markets or because German firms are less dependent on the international market due to the larger size of their domestic market.

On average, in 1997 the firms in our sample employed 19 individuals (German firms: 17 employees; UK firms: 21 employees). In the period between the two surveys, the average number of employees rose by 7 individuals to 26 employees in 2002 (German firms: 27 employees; UK firms: 26 employees). Similarly, the firms’ average volume of sales increased from 1.6 million euro in 1997 (German firms: 1.6 million euro; UK firms: 1.7 million euro) to 3.6 million euro in 2002 (German firms: 3.7 million euro; UK firms: 3.6 million euro; all sales data measured in euro of 2002). ${ }^{3}$ The implied annualised sales growth rate amounts to $12.9 \%$ (German firms: $16.1 \%$; UK firms: 10.5\%). The average volume of (discounted) sales of exporting firms grew significantly faster (according to a conventional t-test) in the period from 1997 to 2002 compared with firms without international business activities. Exporters were able, on average, to realise an annual sales growth rate of $14.6 \%$, whereas firms with only domestic sales grew by $8.3 \%$ per year. This result corresponds to the stylised facts documented by many other studies (e.g., Clerides et al. 1998, Bernard and Wagner 1997, Bernard and Jensen 1999): Firms with international sales exhibit a superior performance (sales growth in our case) when compared with non-exporting firms.

3 Sales data were discounted by producer price indices (PPI) for the 3-digit NACE code of the respective manufacturing sector in Germany or 4-digit NACE code of the corresponding manufacturing sector in the UK, as they are available online from the time series services of the Federal Statistical Office of Germany (https://www-genesis.destatis.de) and the Office for National Statistics in the UK (http://www.statistics.gov.uk). In order to obtain comparable sales data between the German and the UK subsamples, exchange rates from the historical exchange rate database of Oanda Corp. were used (http://www.oanda.com). 


\section{Estimating a Dose-Response Function}

In order to implement the generalised propensity score (GPS) method, Hirano and Imbens (2004) suggest a three-stage approach. In the first stage, the conditional distribution of the treatment variable given the covariates is estimated. In our case, the distribution of the treatment variable, i.e. the firms' export-sales ratio, is highly skewed. In particular, it has many limit observations at the value zero, representing firms without any international sales. The latter group of firms decided that their optimal volume of exports was zero. Following Wagner (2001, 2003), I apply the fractional logit model developed by Papke and Wooldridge (1996) for estimating the export intensity of the firms in our sample. ${ }^{4}$ The estimation procedure maximises the Bernoulli log-likelihood function given by

$$
l_{i}(\beta) \equiv D_{i} \cdot \log \left[\Lambda\left(X_{i} \beta\right)\right]+\left(1-D_{i}\right) \cdot \log \left[1-\Lambda\left(X_{i} \beta\right)\right]
$$

(with $D$ as the firm's export-sales ratio [the treatment], $X$ as the vector of covariates, and $\Lambda(\cdot)$ as the cumulative distribution function of the logistic distribution) using the generalised linear models (GLM) framework developed by McCullagh and Nelder (1989). The derivation of the estimation equation of the fractional logit model as well as a discussion of the results are presented in detail in a companion paper to this study (cf. Fryges 2006) and are therefore omitted for reasons of space. In Table 2, I only reprint the results of the fractional logit model that regresses the 1997 export intensity on a vector of covariates. In short, the results show that for young technology-oriented firms in Germany and the UK neither youth nor smallness is necessarily an obstacle to realising a high export-sales ratio. However, this requires that the firms possess firm-specific assets in order to overcome barriers to entry into the foreign market. These firm-specific

4 Hirano and Imbens (2004) use a normal distribution for (the logarithm of) the treatment variable of their model. However, they emphasise that more general models may be considered. 
assets may be acquired via conducting own R\&D activities, or by employing internationally experienced managers.

>>> insert Table 2 about here $\quad<<<$

Let $r(d, x)$ be the conditional density of the treatment given the covariates:

$$
r(d, x)=f_{D \mid X}(d \mid x)
$$

Then the GPS is defined as $R=r(D, X)$ (Hirano and Imbens 2004: 2). Thus, the estimated GPS based on the Bernoulli likelihood function defined in equation (1) is

$$
\hat{R}_{i}=\left[\Lambda\left(X_{i} \hat{\beta}\right)\right]^{D_{i}} \cdot\left[1-\Lambda\left(X_{i} \hat{\beta}\right)\right]^{\left(1-D_{i}\right)}
$$

Hirano and Imbens (2004) prove that using the GPS eliminates any biases associated with differences in the pre-treatment variables. This bias removing property of the GPS corresponds to that of the traditional binary propensity score as demonstrated by Rosenbaum and Rubin (1983) and used by most of the literature that applied matching techniques. ${ }^{5}$

In the second stage of Hirano and Imbens' GPS methodology the conditional expectation of outcome $Y_{i}$ is modelled as a function of the treatment $D_{i}$ and the (estimated) generalised propensity score $\hat{R}_{i}$. The outcome variable used in this paper is the logarithmic annualised sales growth rate $G$ (see, for example, Evans 1987a, 1987b) which is given by:

5 The bias removal property of the GPS is based on the assumption of weak unconfoundedness which is a generalisation of the (strong) unconfoundedness assumption made by Rosenbaum and Rubin (1983) for binary treatments (cf. Imbens 2000): The treatment $D$ is weakly unconfounded, given pretreatment variables $X$, if $Y(d) \perp D \mid X$ for all realisations $d$ of the treatment $D$, with $Y(d)$ as the outcome associated with treatment level $d$. 
(4) $Y_{i}=\ln G_{i}=\frac{\ln S_{i, t_{2}}-\ln S_{i, t_{1}}}{t_{2}-t_{1}}$,

where $S$ are (discounted) sales of firm $i, t_{1}$ is 1997 and $t_{2}$ is 2002. Following Hirano and Imbens, I use a quadratic approximation for the conditional expectation of $Y_{i}$ :

$$
E\left[Y_{i} \mid D_{i}, R_{i}\right]=\alpha_{0}+\alpha_{1} \cdot D_{i}+\alpha_{2} \cdot D_{i}^{2}+\alpha_{3} \cdot \hat{R}_{i}+\alpha_{4} \cdot \hat{R}_{i}^{2}+\alpha_{5} \cdot D_{i} \cdot \hat{R}_{i}
$$

Equation (5) is estimated by OLS. As Hirano and Imbens point out, the estimated regression coefficients $\alpha$ do not have any direct meaning and are therefore not reported here for reasons of space.

In the last stage of the GPS method, the average expected outcome at treatment level $d$ is estimated, using the regression coefficients $\hat{\alpha}$ from the second stage of the GPS method:

(6) $\widehat{E[Y(d)]}=\frac{1}{N} \sum_{i=1}^{N}\left(\hat{\alpha}_{0}+\hat{\alpha}_{1} \cdot d+\hat{\alpha}_{2} \cdot d^{2}+\hat{\alpha}_{3} \cdot \hat{r}\left(d, X_{i}\right)+\hat{\alpha}_{4} \cdot \hat{r}\left(d, X_{i}\right)^{2}+\hat{\alpha}_{5} \cdot d \cdot \hat{r}\left(d, X_{i}\right)\right)$,

with $N$ as the number of observations in our data set. In order to obtain an estimate of the entire dose-response function, equation (6) is calculated at each level of the treatment, i.e. in our case, at each export intensity in the interval from zero to one, increasing the export intensity successively by one percentage point in each step. Following the same procedure as Hirano and Imbens, the confidence intervals of the dose-response function are determined via bootstrapping.

\section{$>>$ insert Figure 1 about here $\quad<<<$}

The resulting dose-response function is depicted in Figure 1. Generally speaking, the estimated dose-response function shows the inverted $U$-shaped relationship between the pre-treatment (i.e., 1997) export intensity and the subsequent sales growth rate which 
was already demonstrated by various studies from the field of international management (e.g., Geringer et al. 1989 and Gomes and Ramaswamy 1999). The estimated annualised sales growth rate of firms with only domestic sales amounts to $9.5 \%$ (nonlogarithmic value) which exceeds the mean sales growth rate actually observed within the group of non-exporting firms by 1.2 percentage points. Firms that generate a relatively small share of their total sales abroad (less than 10\%) exhibit only a modest increase in their expected sales growth rate when compared with non-exporting firms. The slope of the dose-response function is relatively small within this interval of the pre-treatment export intensity. The maximum value of the expected sales growth rate is reached at an export-sales ratio of $60 \%$, where the expectation value of the annualised sales growth rate amounts to $17.7 \%$ (non-logarithmic value). Firms of which the export intensity exceeds this "threshold value of internationalisation” (Geringer et al. 1989) exhibit a sales growth rate that falls below its maximum value, probably due to the high costs of coordination and control they are faced with and which confine their growth potential.

The dose-response function displayed in Figure 1 suggests a rather deterministic relationship between a firm's export intensity and its performance. Its functional form implies that in order to maximise their firms' performance (i.e. in our case, the future sales growth rate) managers have to realise a predetermined optimal export intensity. However, from a managerial point of view the more important question is how firm managers react once they have recognised a decrease in performance due to "excessive" internationalisation (Sullivan 1994a). Are they able to reorganise their international business activities in order to reduce the costs of coordination and control and reverse the decline in performance? Although this issue is beyond the scope of this paper it should be noted that the firms in our sample are very young (an average of six years old in 1997). Thus, the process of organisational learning on how to deal with the chal- 
lenges of a rising export intensity has probably not yet finished for the firms in our sample. If we were able to track the sampled firms over a longer time period it might be that the observed decrease in performance of firms with a high export-sales ratio disappears, or at least abates, because the firms have undergone such learning processes.

\section{Concluding Remarks}

This paper introduces the generalised propensity score methodology developed by Imbens (2000) and Hirano and Imbens (2004) to the literature of individual firms' export behaviour. Using the GPS method, a dose-response function is estimated, confirming the inverted $U$-shaped relationship between the pre-treatment export intensity and firm performance (measured by the firms' subsequent sales growth rate) that has frequently been found in studies from the field of international management.

However, there are some caveats to the empirical example presented in this paper, primarily related to data restrictions. The number of observations in our data set is relatively small. In particular, the number of firms of which the export intensity exceeds the estimated threshold of internationalisation is limited (only $13 \%$ of the firms sampled), making the estimation of the dose-response function in this region more difficult. Moreover, our sample of newly founded firms was observed only twice with a six year interval between the two surveys. Tracking the firms over a longer time period and building up a panel data set could be a way to get further insights into the exportperformance relationship, in particular with respect to its temporal dimension (e.g., learning processes connected with export activities). The analysis should also be extended to measures of firm performance others than the firms' sales growth rate, for example labour productivity, total factor productivity, profits, or wages. 
Another caveat to the analysis is linked with the limited size of the data set. Although the estimated dose-response function shows a plausible relationship between the firms' pre-treatment export intensity and the subsequent sales growth rate, the estimated $90 \%$ confidence interval is relatively large at each point at which the dose-response function was evaluated. Moreover, the confidence interval increases with the export intensity. It is therefore questionable whether or not the maximum expected sales growth rate is significantly larger than the respective growth rate of non-exporting firms. This analysis, however, is beyond the scope of this paper.

In summary, the generalised propensity score method applied in this paper constitutes a new econometric technique that offers numerous opportunities for future research and promises to provide new insights into the export-performance relationship. 


\section{Acknowledgements}

I gratefully acknowledge financial support from the HSBC Innovation and Technology Group and the Anglo-German Foundation for the Study of Industrial Society. Helpful suggestions by Dirk Czarnitzki, Joachim Wagner, and Michael Woywode are also gratefully acknowledged. I thank Marc Rennert for his competent research assistance and Andrew Flower for proofreading. Special thanks go to Marc Cowling and Gordon Murray for carrying out the survey this study is based on in the UK. Any errors that remain are my own.

\section{References}

Bernard, A. B., and J. B. Jensen (1999) Exceptional Exporter Performance: Cause, Effect, or Both?, Journal of International Economics, 47, 1--25.

Bernard, A. B., and J. Wagner (1997) Exports and Success in German Manufacturing, Review of World Economics, 133 (1), 134--57.

Bühner, R. (1987) Assessing International Diversification of West German Corporations, Strategic Management Journal, 8, 25--37.

Bürgel, O., A. Fier, G. Licht, and G. C. Murray (2004) The Internationalisation of Young High-Tech Firms, ZEW Economic Studies, 22, Heidelberg, New York.

Butchart, R. (1987) A New UK Definition of High-Technology Industries, Economic Trends, 400, 82--88.

Castellani, D. (2002) Export Behavior and Productivity Growth: Evidence from Italian Manufacturing Firms, Review of World Economics, 138 (4), 605--28.

Clerides, S. K., S. Lach, and J. R. Tybout (1998) Is Learning by Exporting Important? Micro-Dynamic Evidence from Colombia, Mexico, and Morocco, The Quarterly Journal of Economics, 113 (3), 903--47.

Evans, D. S. (1987a) Tests of Alternative Theories of Firm Growth, Journal of Political Economy, 95 (4), 657--74.

Evans, D. S. (1987b) The Relationship between Firm Growth, Size, and Age: Estimates for 100 Manufacturing Industries, Journal of Industrial Economics, 35 (4), 567--81.

Feder, G. (1982) On Exports and Economic Growth, Journal of Development Economics, 12, 59--73.

Fryges, H. (2004) Productivity, Growth and Internationalisation: The Case of German and British High Techs, ZEW Discussion Paper No. 04-79, Mannheim. 
Fryges, H. (2006) Hidden Champions - How Young and Small Technology-Oriented Firms Can Attain High Export-Sales Ratios, forthcoming as ZEW Discussion Paper, Mannheim.

Geringer, J. M., P. W. Beamish, and R. C. daCosta (1989) Diversification Strategy and Internationalization: Implications for MNE Performance, Strategic Management Journal, 10 (2), 109--19.

Gomes, L., and K. Ramaswamy (1999) An Empirical Examination of the Form of the Relationship Between Multinationality and Performance, Journal of International Business Studies, 30 (1), 173--88.

Grant, R. M. (1987) Multinationality and Performance among British Manufacturing Companies, Journal of International Business Studies, 18 (3), 79--89.

Hirano, K., and G. W. Imbens (2004) The Propensity Score with Continuous Treatments, Working Paper, University of California, Berkeley.

Hitt, M. A., R. E. Hoskisson, and R. D. Ireland (1994) A Mid-Range Theory of the Interactive Effects of International and Product Diversification on Innovation and Performance, Journal of Management, 20 (2), 297--326.

Imbens, G. W. (2000) The Role of the Propensity Score in Estimating Dose-Response Functions, Biometrika, 83, 706--10.

Liu, J.-T., M.-W. Tsou and J. K. Hammitt (1999) Export Activities and Productivity: Evidence from the Taiwan Electronics Industry, Review of World Economics, 135 (4), 675--91.

McCullagh, P., and J. A. Nelder (1989) Generalized Linear Models, second edition, New York: Chapman and Hall.

Papke, L. E., and J. M. Wooldridge (1996) Econometric Methods for Fractional Response Variables with an Application to 401(K) Plan Participation Rates, Journal of Applied Econometrics, 11 (4), 619--32.

Riahi-Belkaoui, A. (1998) The Effects of the Degree of Internationalization on Firm Performance, International Business Review, 7 (3), 315--21.

Rosenbaum, P. R., and D. B. Rubin (1983) The Central Role of the Propensity Score in Observational Studies for Causal Effects, Biometrika, 70 (1), 41--55.

Sullivan, D. (1994a) The “Threshold of Internationalization:” Replication, Extension, and Reinterpretation, Management International Review, 34 (2), 165--86.

Sullivan, D. (1994b) Measuring the Degree of Internationalization of a Firm, Journal of International Business Studies, 25 (2), 325--42.

Wagner, J. (2001) A Note on the Firm Size - Export Relationship, Small Business Economics, 17 (4), 229--37.

Wagner, J. (2002) The Causal Effects of Export on Firm Size and Labour Productivity: First Evidence from a Matching Approach, Economics Letters, 77, 287--92.

Wagner, J. (2003) Unobserved Firm Heterogeneity and the Size-Exports Nexus: Evidence from German Panel Data, Review of World Economics, 139 (1), 161--72.

Wagner, J. (2005) Exports and Productivity: A Survey of the Evidence from Firm Level Data, Working Paper Series in Economics, No. 5, University of Lüneburg, Lüneburg, forthcoming in The World Economy. 


\section{Appendix}

\section{Table 1: Definition of High-Tech Sectors}

\begin{tabular}{|c|c|c|}
\hline $\begin{array}{l}\text { Aggregated } \\
\text { industries used }\end{array}$ & $\begin{array}{l}\text { NACE } \\
\text { Rev. } 1\end{array}$ & Short description according to NACE Rev.1 \\
\hline $\begin{array}{l}\text { R\&D-Intensive } \\
\text { Service Indus- } \\
\text { tries }\end{array}$ & $\begin{array}{l}64.20 ; 72.20 \\
72.30 ; 72.40 \\
72.60 ; 73.10\end{array}$ & $\begin{array}{l}\text { Telecommunication, Computer Programming and Software Services, } \\
\text { Data Processing, Misc. Computer Services, R\&D in Natural Sciences } \\
\text { and Engineering }\end{array}$ \\
\hline ICT-Hardware & $\begin{array}{l}30.01 ; 30.02 \\
32.20 ; 32.30\end{array}$ & $\begin{array}{l}\text { Office Equipment; Computers and other Information Processing } \\
\text { Equipment; Television and Radio Transmitters and Apparatus for Line } \\
\text { Telephony and Line Telegraphy; Television and Radio Receivers, } \\
\text { Sound or Video Recording and Reproducing Apparatus }\end{array}$ \\
\hline $\begin{array}{l}\text { Engineering } \\
\text { Industries }\end{array}$ & $\begin{array}{l}33.20 ; 33.30 \\
33.40\end{array}$ & $\begin{array}{l}\text { Electronic Instruments and Appliances for Measuring, Checking } \\
\text { (except Industrial Process Control); Electronic Industrial Process } \\
\text { Control Equipment; Optical Instruments; Photographic Equipment }\end{array}$ \\
\hline $\begin{array}{l}\text { Health and Life } \\
\text { Sciences }\end{array}$ & $\begin{array}{l}24.41 ; 24.42 \\
33.10\end{array}$ & $\begin{array}{l}\text { Pharmaceutical Products and Preparations; Medical and Surgical } \\
\text { Equipment and Orthopaedic Appliances }\end{array}$ \\
\hline $\begin{array}{l}\text { Other High-Tech } \\
\text { Manufacturing }\end{array}$ & $\begin{array}{l}24.16 ; 24.17 \\
31.10 ; 31.20 \\
32.10 ; 35.30\end{array}$ & $\begin{array}{l}\text { Plastics and Synthetic Rubber in Primary Form; Electric Motors, } \\
\text { Generators and Transformers; Electricity Distribution and Control } \\
\text { Apparatus; Electronic Valves, Tubes and other Components; Aircraft } \\
\text { and Spacecraft Manufacturing }\end{array}$ \\
\hline
\end{tabular}

Source: Manufacturing sector: Butchart (1987); service sector: Bürgel et al. (2004). 
Table 2: Fractional Logit Model: Pre-Treatment Export-Sales Ratio (1997)

\begin{tabular}{|c|c|c|c|}
\hline \multirow[b]{2}{*}{ Exogenous variables } & \multicolumn{3}{|c|}{$\begin{array}{c}\text { Number of observations }=173 \\
\qquad \begin{array}{c}\mathrm{LL}=-70.615 \\
\chi^{2}(18)=66.01 \\
\text { Prob }>\chi^{2}(18)=0.000 \\
\mathrm{R}^{2}=0.224\end{array}\end{array}$} \\
\hline & Coeff. & $\begin{array}{c}\text { Robust } \\
\text { stand. error }\end{array}$ & \\
\hline 1 Dummy Western Germany & -0.269 & 0.297 & \\
\hline 2 Dummy Eastern Germany & -1.269 & 0.402 & $* * *$ \\
\hline 3 Dummy engineering industry & 0.861 & 0.357 & $* *$ \\
\hline 4 Other manufacturing industries & 0.671 & 0.313 & $* *$ \\
\hline 5 Log (number of employees) & 0.582 & 0.667 & \\
\hline 6 Log (number of employees) ${ }^{2}$ & -0.056 & 0.111 & \\
\hline 7 Log (age in years) & -0.034 & 0.372 & \\
\hline 8 Permanent R\&D activities & 0.896 & 0.471 & $*$ \\
\hline 9 Occasional R\&D activities & 0.892 & 0.489 & $*$ \\
\hline 10 Novel self-developed technology & -0.098 & 0.262 & \\
\hline 11 Novel techn., developed elsewhere & 0.444 & 0.284 & \\
\hline 12 Working experience abroad & 0.630 & 0.276 & $* *$ \\
\hline 13 Education abroad & 0.219 & 0.309 & \\
\hline \multicolumn{4}{|l|}{14 Shortage in competencies } \\
\hline Sales/distribution & -0.126 & 0.297 & \\
\hline Production/R\&D & 0.049 & 0.301 & \\
\hline 15 Intense product customisation & -0.470 & 0.239 & $* *$ \\
\hline 16 Regular maintenance and upgrades & -0.180 & 0.291 & \\
\hline 17 Dummy consumer good & 0.040 & 0.233 & \\
\hline Constant & -3.498 & 1.382 & $* *$ \\
\hline
\end{tabular}

* $10 \%$ level of significance; ** 5\% level of significance; *** $1 \%$ level of significance.

Base category: UK-based software firm without R\&D activities.

Definition of exogenous variables:

8/9 Permanent and occasional R\&D activities as indicated by firm representatives.

10 The firm's best-selling product or service incorporates novel technology that had to be developed specifically for this product by the company.

11 The firm's best-selling product or service incorporates novel technology that has been developed elsewhere.

12/13 At least one member of the firm's management team had work experience abroad or was educated abroad before he made his first international sales.

14 Firm managers experience a "serious" or "very serious" shortage of skills in sales/distribution and production/R\&D respectively, measured on a five point Likert scale.

15/16 Firm managers classified the requirement of "individual client customisation" and "regular maintenance and upgrades" of their best-selling product or service as "important" or "very important”, measured on a five point Likert scale.

Source: Fryges (2006). 


\section{Figure 1: Estimated Dose-Response Function}

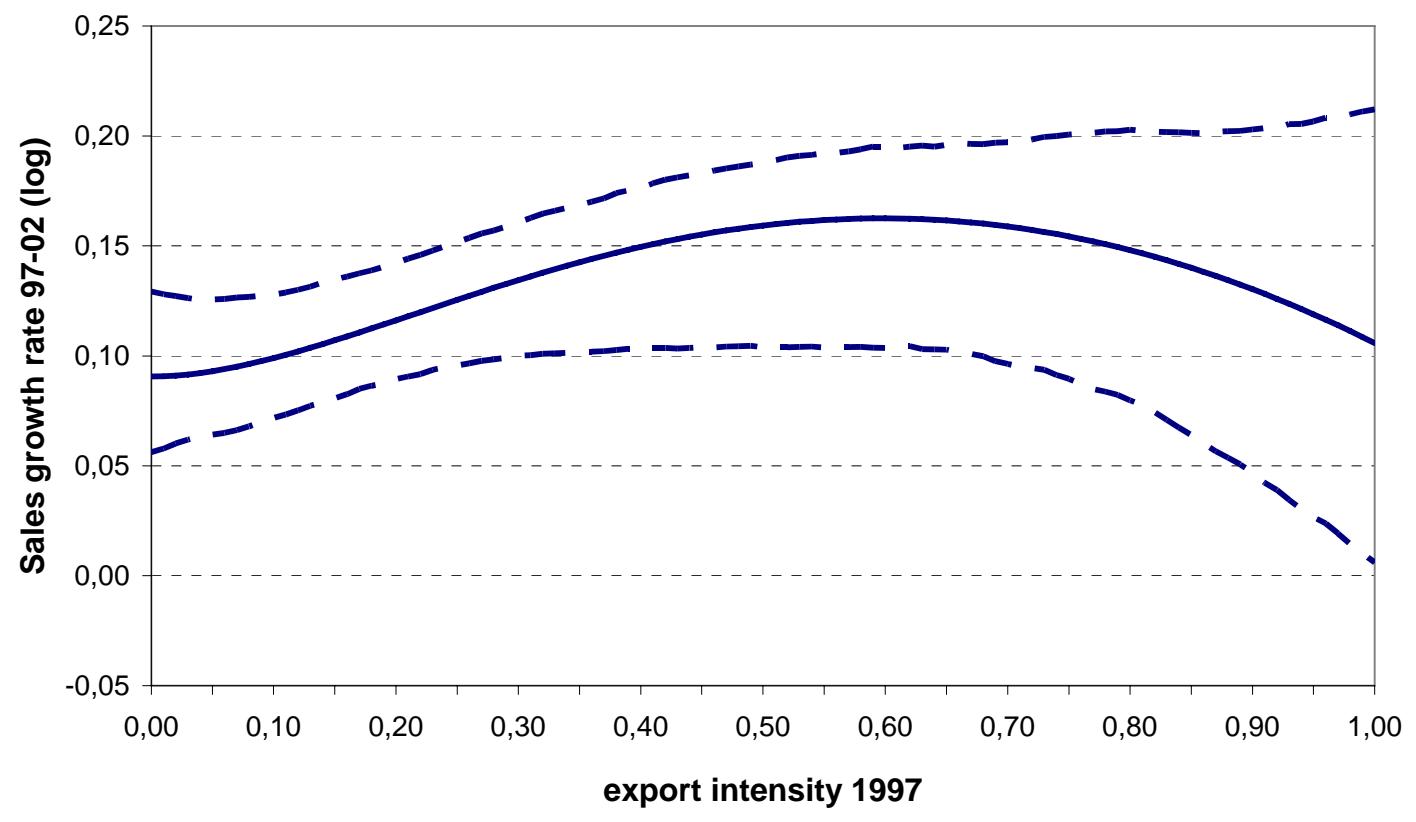

Annualised sales growth rates are computed using discounted sales.

Solid line: estimated conditional expectation of the firms' sales growth rate 1997-2002 given the export intensity 1997 and the estimated generalised propensity score (GPS).

Dotted lines: simulated $90 \%$ confidence interval, using the $5 \%$ and $95 \%$ percentiles of the bootstrap distribution (1,000 replications).

Source: own estimation. 